Article

\title{
Sustainable Use of Petrothermal Resources-A Review of the Geological Conditions in Poland
}

\author{
Anna Sowiżdżał ${ }^{1, *(1)}$, Paweł Gładysz ${ }^{2}$ and Leszek Pająk ${ }^{1}$ \\ 1 Faculty of Geology, Geophysics and Environmental Protection, AGH University of Science and Technology, \\ 30-059 Kraków, Poland; pajakl@agh.edu.pl \\ 2 Faculty of Energy and Fuels, AGH University of Science and Technology, 30-059 Kraków, Poland; \\ pawel.gladysz@agh.edu.pl \\ * Correspondence: ansow@agh.edu.pl
}

\section{check for}

updates

Citation: Sowiżdżał, A.; Gładysz, P.; Pają, L. Sustainable Use of Petrothermal Resources-A Review of the Geological Conditions in Poland. Resources 2021, 10, 8 . https://doi.org/10.3390/resources 10010008

Received: 2 November 2020

Accepted: 15 January 2021

Published: 18 January 2021

Publisher's Note: MDPI stays neutral with regard to jurisdictional claims in published maps and institutional affiliations.

Copyright: (c) 2021 by the authors. Licensee MDPI, Basel, Switzerland. This article is an open access article distributed under the terms and conditions of the Creative Commons Attribution (CC BY) license (https:/ / creativecommons.org/licenses/by/ $4.0 /)$.

\begin{abstract}
This article considers the possibility of using unconventional geothermal resources in enhanced geothermal systems (EGSs) under Polish geological conditions. In order to obtain additional environmental benefits, EGS systems using $\mathrm{CO}_{2}$ as a medium were analyzed. In addition to the production of clean energy, this allows for the geological storage of $\mathrm{CO}_{2}$ during the energy production process. The aim of this paper is to analyze the geological conditions for EGS- $\mathrm{CO}_{2}$ systems. Criteria is established for selecting an optimal location for the implementation of the first pilot installation of this type in Poland. Due to the depth of deposition and predicted thermal and petrophysical parameters, the optimal location occurs in sedimentary rocks in the central part of the Polish Lowland (Krośniewice-Kutno area). However, other favorable zones meeting the established criteria for simultaneous energy production and $\mathrm{CO}_{2}$ sequestration have been identified in northwestern parts of Poland (Szczecin Trough) and in southern Poland, in the area of the Carpathian Foredeep (Upper Silesia region).
\end{abstract}

Keywords: enhanced geothermal system; $\mathrm{CO}_{2}$ sequestration; petrothermal resources; geothermal energy; carbon capture and storage; Poland

\section{Introduction}

Access to affordable energy sources is crucial to ensuring a high standard of living of society and maintaining sustainable economic development. This access is necessary to meet the needs for energy supply and is the basis of industry and technological development. Efficient use of energy is a key factor affecting production costs and the competitiveness of products on the international market. Unreasonable energy use leads to environmental pollution problems, including $\mathrm{CO}_{2}$ emissions and the depletion of natural energy resources. The growing demand for energy resulting from development as well as protection of the natural environment make it necessary to search for new innovative technologies for obtaining energy. In the 21st century, the use of more ecological and competitively priced renewable energies is gaining importance. This is crucial in the context of reducing emissions of pollutants into the air, whose quality depends on the use of fuels in a given country.

The sustainable use of natural resources is associated with the exploration of alternative and innovative solutions aimed at generating energy in the most environmentally friendly and efficient way. One of the basic environmental problems in Poland is caused by the excessive use of fossil fuels. The Polish energy sector, based on coal combustion, requires changes in order to implement modern and ecological technologies. Currently in Poland, the basic source of energy is still hard coal (57.9\%). The share of energy from renewable sources in 2018 was $11.16 \%$. This energy came mainly from solid biofuels (69\%), wind energy (13\%) and liquid biofuels (10\%) [1]. The share of geothermal energy in total renewable energy sources (RES) energy production was negligible and was below $1 \%$. 
Such an energy structure is very impactful on the state of the environment in Poland. In the structure of greenhouse gas emissions in Poland, carbon dioxide had a dominant share $-\mathrm{CO}_{2}$ accounted for as much as $81.3 \%$ of total gas emissions, with the others being methane $(11.9 \%)$, nitrous oxide $(5 \%)$ and halogenated hydrocarbons $(1.7 \%)$. The energy sector had a decisive impact on carbon dioxide emissions (93.9\%); the remaining 5.7\% were due to industrial processes and production [1]. These data clearly show that changes in the energy structure are needed as well as a fundamental reduction of $\mathrm{CO}_{2}$ emissions from the combustion of fossil fuels. Deep geothermal energy is a future source of energy, and its resources have great potential for the development of future electricity and heat production. Additionally, its application brings many environmental highlights, because it is renewable, sustainable and clean [2].

There are two primary geothermal systems, based on their geologic characteristics: convection-dominated and conduction-dominated geothermal systems. Convectiondominated systems are related to high enthalpy resources and occur at plate tectonic margins or settings of active tectonism or volcanism. Conduction-dominated geothermal systems host low to medium enthalpy resources and can be classified into hydrothermal and petrothermal systems. Petrothermal systems, in contrast to hydrothermal systems, do not contain enough fluid volume for heat extraction [3]. One of the innovative technologies for using these kinds of resources is an enhanced geothermal system (EGS). The idea of utilizing petrothermal energy accumulated in hot compact rocks not containing any water was conceived in 1970. At that time, the concept of utilizing the Earth's heat in closed geothermal systems by artificially increasing the hydraulic capacity of the geothermal reservoir was developed (Figure 1). This method was put forward in the Los Alamos Laboratory [4].

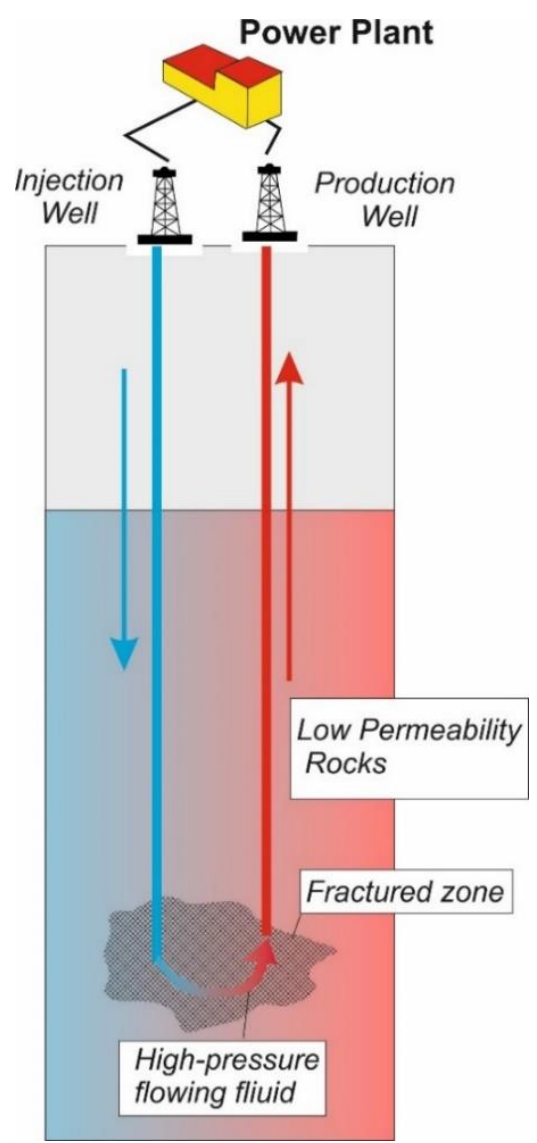

Figure 1. The concept of enhanced geothermal system (modified in accordance with [5]). 
The basic elements of such a system are the creation of a fracture network and the injection working fluid via injection wells. Induced heated fluid is recovered from the production wells for energy generation. The temperature of reservoir rocks is a key factor, and it should exceed $150{ }^{\circ} \mathrm{C}[5,6]$. Heat transfer between working fluid and rock formation occurs as the effect of significant temperature difference. The temperature of working fluid is much lower than the rock mass, thus, the working medium can gain heat. The energy of the Earth's crust accumulated in the working fluid is then transported to the surface. Extracted energy might be used for electricity production, which is an indirect utilization of geothermal energy. On the other hand, the extracted energy is utilized in a direct way for heating purposes.

The EGS working fluid in most plants is water $\left(\mathrm{H}_{2} \mathrm{O}\right)$; however, carbon dioxide $\left(\mathrm{CO}_{2}\right)$ is the second possible solution [7]. Enhanced geothermal systems (EGSs) with $\mathrm{CO}_{2}$ as a medium have the additional ecological benefits of $\mathrm{CO}_{2}$ geological storage during the energy generation process. The concept of such a system to reduce carbon dioxide emissions and simultaneously produce energy has been proposed by Brown [8]. This technology has other advantages besides the possibility of geological $\mathrm{CO}_{2}$ storage. Research [9-12] has shown that the use of $\mathrm{CO}_{2}$ instead of water as a working fluid is characterized by favorable transport properties, self-propelled high flow rates and low chemical activity as well as low salt solubility. One of the first experiences with the EGS- $\mathrm{CO}_{2}$ system involved the experiments carried out in 1989-2001 at the Ogachi EGS plant. The petrothermal reservoir was granodiorite, with a temperature exceeding $230^{\circ} \mathrm{C}$ at a depth of $1000 \mathrm{~m}$ [13]. Field as well as laboratory experiments indicated the ability to store $\mathrm{CO}_{2}$ in unconventional geothermal systems, related to the precipitation of carbonates and clay minerals, by injecting $\mathrm{CO}_{2}$ into geothermal reservoirs [14-16]. Scientists emphasized the significant ecological benefits of this innovative solution $[17,18]$.

The first step in developing an EGS- $\mathrm{CO}_{2}$ system is to find an appropriate geological structure. The selection of the proper location has significant impact on the economic effect of the project $[19,20]$. Geothermal energy accumulated in deep geological structures is associated with hydrothermal (connected with groundwater) or petrothermal (hot dry rocks) systems. Hydrothermal systems in Poland are relatively well recognized and currently used [21-24], while the recognition of petrothermal systems is in the early stages [25-27]. This study analyses the possibility of creating an EGS- $\mathrm{CO}_{2}$ system in Poland under specific geological conditions. This method combines geothermal energy utilization with $\mathrm{CO}_{2}$ sequestration for environmental benefits.

\section{Materials and Methods}

The selection of a suitable location for EGS systems utilizing $\mathrm{CO}_{2}$, is dependent on geological and hydrogeological conditions as well as the geothermal parameters for $\mathrm{CO}_{2}$ storage. The analytical work proceeded in three stages. The first stage was to identify the most favorable zones for underground carbon capture and storage in Poland. In the second stage, the possibilities of constructing unconventional geothermal systems were indicated. An integrated analysis of both stages allowed for the determination of the possibility of building an EGS- $\mathrm{CO}_{2}$ system with $\mathrm{CO}_{2}$ geological storage (stage three). After establishing the criteria, the available source materials were analyzed. An analysis of the geological conditions enabling the construction of the system was carried out. The identified petrothermal reservoirs were characterized in terms of their suitability for the storage of carbon dioxide. Published and unpublished geological information in the form of maps and geological cross-sections, borehole data, results of laboratory tests on cores, thermograms and published subject literature were used as source materials.

It was assumed that the system would ultimately consist of a biomass-fired combined heat and power plant $(\mathrm{CHP}), \mathrm{CO}_{2}$ capture and compression unit, $\mathrm{CO}_{2}$ transport pipeline, geothermal system as well as a supercritical $\mathrm{CO}_{2}$ Brayton power cycle. This work focuses on the geological aspects of the functioning of such a system. Thus, the aim was to check whether there are appropriate geological conditions in Poland for the construction of a 
biomass heat and power plant, from which $\mathrm{CO}_{2}$ would be captured and injected as a medium to the EGS- $\mathrm{CO}_{2}$ system.

\subsection{Criteria for Selecting an Optimum Structure for Carbon Capture and Storage (CCS) in Poland}

Carbon capture and storage (CCS) can be considered when there are adequate geological conditions. The best areas for this purpose seem to be sedimentary basins located in tectonically stable zones, without contemporary volcanism and earthquakes. Sedimentary basins are the best for the geological sequestration of $\mathrm{CO}_{2}$ because they possess the right type of porous and permeable rocks [28]. The basic geological condition that determines the possibility of underground storage of large amounts of $\mathrm{CO}_{2}$ is the presence of sedimentary rocks of significant thickness and extent having good collection properties and with a good insulating rock cover [29].

In the long term, underground $\mathrm{CO}_{2}$ storage is controlled by the impact of four basic mechanisms [30]:

- immobilization in reservoir traps-replacement of reservoir fluids with $\mathrm{CO}_{2}$,

- solution in surrounding reservoir fluids,

- $\quad$ geochemical reactions with reservoir fluids or rock building minerals, and

- if sealing is not perfect, migration outside the reservoir, where geological storage is performed.

An optimum structure for carbon capture and storage should be located at a suitable depth to ensure the required pressure and $\mathrm{CO}_{2}$ injection efficiency. Reservoir rocks should be characterized by adequate porosity and permeability to ensure appropriate storage capacity as well as be covered with impermeable rock of appropriate thickness. A proper geological structure will form a structural or stratigraphic trap, most preferably in the form of a high-capacity anticline. An important element is to determine whether the rock formation is appropriate for $\mathrm{CO}_{2}$ storage, which should be localized below any used aquifers as well as separated from them by one or several layers of impermeable insulation rocks, preventing gas from getting through to potable water levels located above. The absorbent zone of the level selected for storage should be characterized with sufficient rock porosity to receive as much injected gas as possible. The $\mathrm{CO}_{2}$ injection area should be geologically stable. $\mathrm{CO}_{2}$ storage should take place with no gas migration to other layers. The strength of the insulating layers is of great importance, including the plasticity of the layers. These parameters influence the fracturing phenomenon and, in some cases, layer puncture can result from excessive injection pressure.

The geological structure itself has to meet a number of conditions, such as depth, volume, thickness of isolating overburden, reservoir tightness, and the permeability and porosity of rocks determining storage capacity for $\mathrm{CO}_{2}$ as well as hydrogeological contacts. Geological structures appropriate for underground $\mathrm{CO}_{2}$ storage in Poland were recognized in a number of projects, studies and analyses [31-33]; however, these concerned mainly $\mathrm{CO}_{2}$ sequestration in depleted gas and oil reservoirs, deep coalbeds and deep aquifers. The potentials for simultaneous $\mathrm{CO}_{2}$ storage and energy production in unconventional geothermal systems in Poland has been presented in a few previous works $[19,20,34]$.

\subsection{Criteria for Selecting an Optimum Structure for Enhanced Geothermal Systems (EGSs) in Poland}

The search for optimal zones was started by setting appropriate critical requirements for the EGS location. The criteria were established on the basis of international experience [4,35-38] as well as the results of projects carried out in Poland [25,26,39,40].

Previous international experience shows that appropriate reservoirs should be searched at depths exceeding $4 \mathrm{~km}$. The reservoir rock should be characterized by low initial permeability in order to guarantee connectivity between the injection and production wells after fracturing, circulating fluids without large pressure losses and generating the right amount of power [14]. In order to obtain economical amounts of heat from low-permeable geothermal reservoirs, it is crucial to maintain a high mass flow rate and a high thermodynamic 
efficiency of the circulating fluid $[35,36]$. The thermo-physical parameters of the rock are of key importance. The possibility of using geothermal energy is determined mostly by the sufficient amount of heat concentration in the drillable depth of the Earth's crust [3]. There are a number of important parameters determining the effective management of geothermal resources, which include both technology development for, and the thermo-physical characteristics of, reservoir formation (including lithological and mechanical properties of reservoir rocks, reservoir thickness, undisturbed temperature, thermal conductivity, thermal diffusivity, heat capacity, primary or fracture porosity, density, mineralogical compositions, presence of groundwater and its hydraulic gradient, etc.).

Finally, four basic criteria for EGS site selection were established:

(1) temperatures of reservoir rocks-minimum $150{ }^{\circ} \mathrm{C}$,

(2) reservoir thickness-minimum $300 \mathrm{~m}$,

(3) low values of petrophysical parameters, and

(4) reservoir depth—at least $4 \mathrm{~km}$.

These parameters are not the only key ones, but taking them into account at the initial stage of the research makes it possible to indicate prospective sites for further detailed research.

The current utilization of geothermal energy in Poland relates mainly to the hydrothermal resources in the Polish Lowlands and Inner Carpathians (Podhale), where geothermal heat plants are presently operating and new ones are at different stages of construction [22]. Petrothermal resources connected with EGS are not currently developed, but some analytical work on this issue has been carried out [26]. The presence of water is particularly important for hydrothermal exploration. Petrothermal reservoirs are characterized by different conditions; therefore, thermal parameters are of the greatest importance. Heat flow and thermal conductivity of rocks affect the temperature distribution within geothermal reservoirs. The key element of this work was thermal analysis together with an analysis of the geological structure of the region.

\section{Geological and Thermal Conditions}

Poland is located at the interface between three main European geostructural units: the Variscan West European Platform (WEP), the Precambrian East European Platform (EEC), and the Carpathian range (part of the Alpine system) (Figure 2). The southwest margin of Precambrian East European Platform is marked as the Teisseyre-Tornquist Zone (TTZ), which extends to the north as the Sorgenfrei-Tornquist Zone (STZ) [41]. The southwestern edge of the EEC is the Trans-European Suture Zone (TESZ), which has a width of approximately 100-200 km (Figure 2) [42].

Geothermal resources are determined by geological, hydrogeological and heat transfer characteristics [3]. Due to the specific geological structures, and therefore different geothermal conditions, Poland can be divided into four major hydrothermal provinces (Figure 2): Polish Lowlands, Carpathian Foredeep, Carpathians and Sudetes. In the area of the largest hydrothermal province, i.e., the Polish Lowlands, the most prospective sources for the use of geothermal waters are Lower Cretaceous and Lower Jurassic reservoirs, from which exploited waters are currently used for heating, recreational and balneotherapeutic purposes [22]. Another perspective area for the use of hydrothermal resources is the Inner Carpathian-Podhale region (southern part of Poland, Western Carpathians). These structures relate mainly to hydrothermal resources; there are no petrothermal provinces in Poland. 




Figure 2. Geological map of Poland without Cenozoic formations (modified in accordance with [43], simplified).

The terrestrial heat flow density in Poland is varied [44,45]. The overall pattern of the heat flow distribution reflects the subsurface geological structure. High heat flow values are observed across the Paleozoic platform, especially in areas of the Variscan externides. Low values are observed in the Precambrian platform; they are extremely low in areas where rock massifs have low radiogenic heat productivity. A distinct change is observed in the range of heat flow density variability that falls within the interval from approximately $38 \mathrm{~mW} / \mathrm{m}^{2}$ in the northeastern part of Poland (the Suwałki Massif) to almost $107 \mathrm{~mW} / \mathrm{m}^{2}$ in the Fore-Sudetic Monocline. In adjoining areas where granitoids are dominant in the basement, the mean heat flow density is $55-65 \mathrm{~mW} / \mathrm{m}^{2}$. In the western end of the Pomeranian Trough, there is an area of elevated heat flow values ranging from over $70 \mathrm{~mW} / \mathrm{m}^{2}$ to $80 \mathrm{~mW} / \mathrm{m}^{2}$. It continues into the Baltic Sea area. The Kujawy-Pomerania Swell, with its numerous salt structures, is manifested as a zone of elevated heat flow values $\left(65-89 \mathrm{~mW} / \mathrm{m}^{2}\right)$ as compared with the East European Craton. The zone of the Miechów Trough shows elevated heat flow values of $65-95 \mathrm{~mW} / \mathrm{m}^{2}$, and the eastern zone is manifested by low heat flow values in the northern end of the Carpathian Foredeep. The Carpathians, in particular their western regions, are characterized by the low heat flow density gradually increasing eastwards. The Sudetes are very poorly explored in terms of thermal conditions, especially in the western regions. A region of increased heat flow rate is the Upper Silesia region, where heat flow values reached the highest measured level in Poland of over $107 \mathrm{~mW} / \mathrm{m}^{2}$ [44] (Figure 3). 


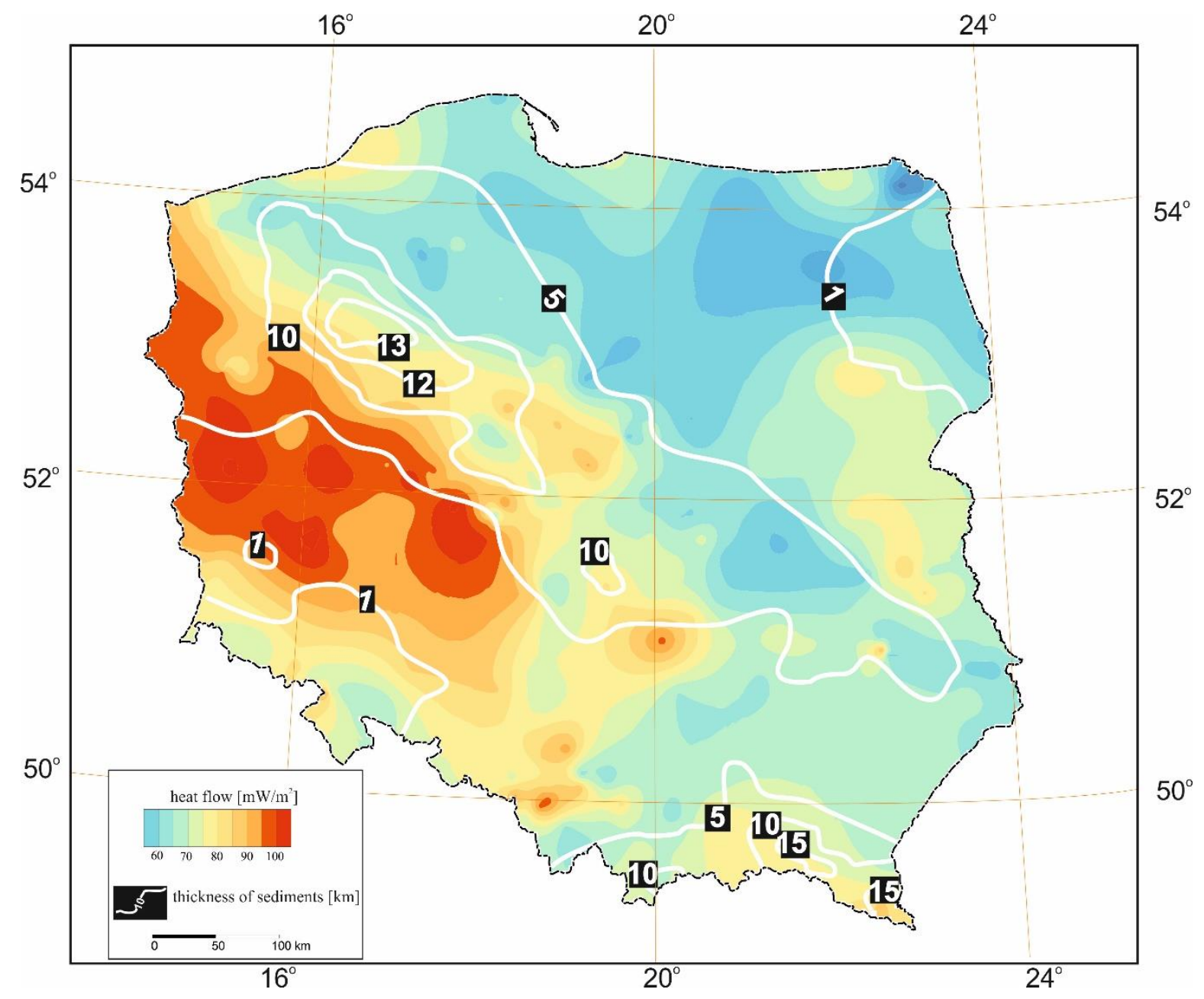

Figure 3. Thickness of sediments in the area of Poland (based on [41]) on the background of heat flow map (modified in accordance with [44]).

Thermal conductivity is strongly dependent on the type of rock; however, due to a number of factors, such as mineralogical composition, fluid content, temperature, etc., it is characterized by a large range of values within the same type of rock [46]. For sedimentary rocks, it is in the wide range of 0.59 to $7.7 \mathrm{~W} / \mathrm{mK}$ (Table 1 ). The highest values are reported for anhydrites [46]. The values of this parameter for igneous rocks increase with depth in the crust and are in the range from 1.00 to $5.86 \mathrm{~W} / \mathrm{mK}$, while for metamorphic rocks values vary from 0.65 to $8.15 \mathrm{~W} / \mathrm{mK}$. Unfortunately, according to research conducted by Majorowicz [41], there is no reliable data on the distribution of sedimentary cover thermal conductivity in Poland. Table 1 shows data from the literature review summarized in [46].

Table 1. Thermal conductivity of sedimentary rocks, $\mathrm{W} / \mathrm{mK}$ [46].

\begin{tabular}{ccc}
\hline Type of Rock & Min Value & Max Value \\
\hline Sedimentary rocks & 0.59 & 7.70 \\
Conglomerate & 1.50 & 5.10 \\
Sandstone & 0.72 & 6.50 \\
Clay-mudstone & 0.59 & 3.48 \\
Limestone & 0.60 & 5.01 \\
Dolomite & 0.61 & 5.73 \\
Marlstone & 1.78 & 2.90 \\
Gypsum & 1.15 & 2.80 \\
Anhidrite & 1.50 & 7.70 \\
\hline
\end{tabular}




\section{An Overview of Hydrogeological Conditions and Thermo-Physical Properties in Poland}

\subsection{Enhanced Geothermal System (EGS)}

Applications of the EGS technology in Poland were analyzed for three different geological conditions: crystalline, volcanic, and sedimentary rock outcropping areas [25] (Figure 4).

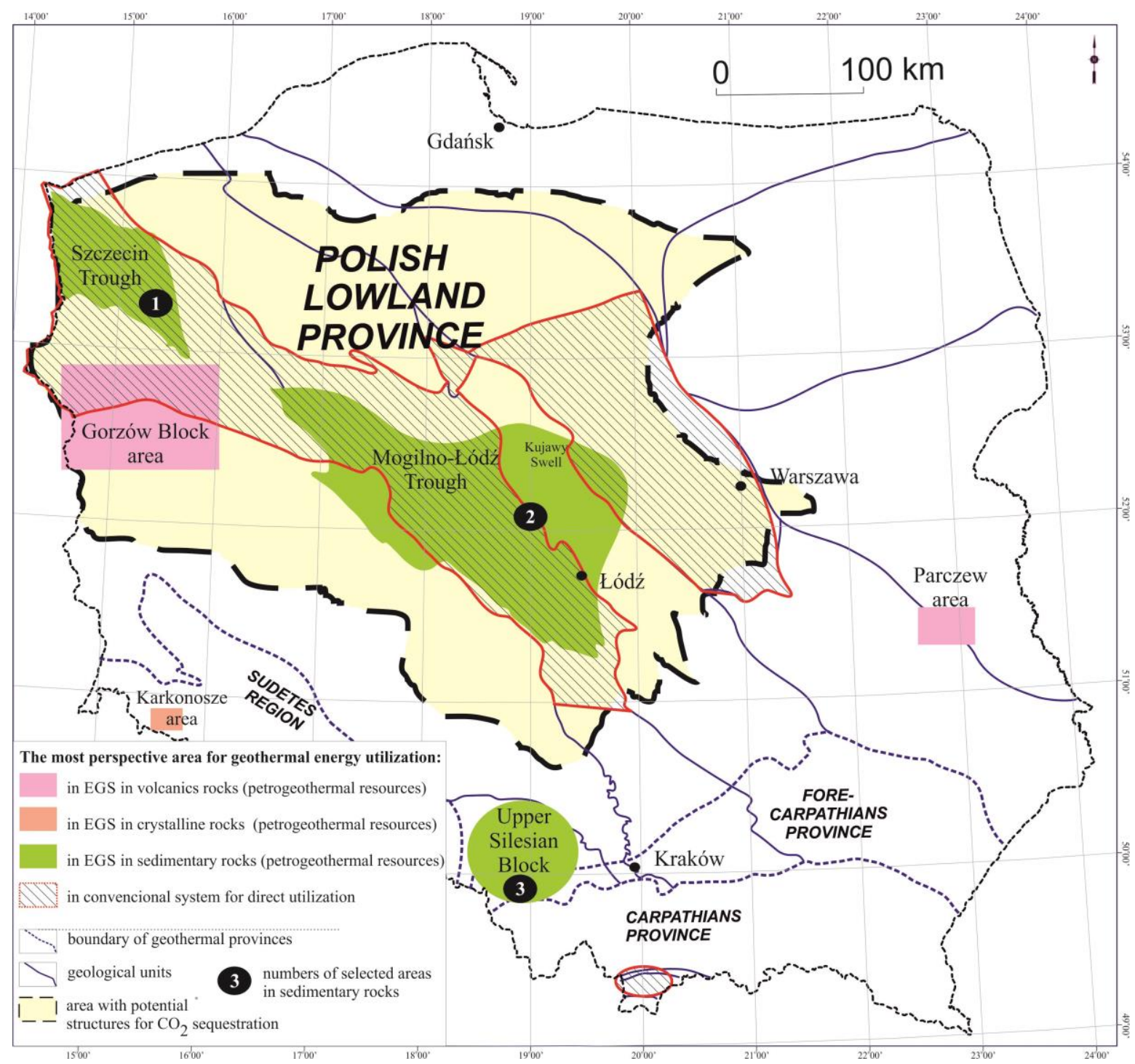

Figure 4. The most prospective areas in Poland for geothermal energy utilization in enhanced geothermal systems (EGSs) as well as $\mathrm{CO}_{2}$ sequestration.

In Poland, outcrops of igneous rocks, which are interesting in terms of the application of EGS technology, with relatively large areas and volumes occur in the south (Sudetes and Fore-Sudetic block) and continue in the Czech Republic. The most interesting area for the application of EGS technology in crystalline rocks was identified in Karkonosze pluton (part of Sudetes). This area is characterized by favorable thermal conditions: the geothermal gradient is approximately $4^{\circ} \mathrm{C} / 100 \mathrm{~m}$ and the temperature reaches $165^{\circ} \mathrm{C}$ at a depth of $4000 \mathrm{~m}$ below sea level Due to the elevated temperature on a regional scale and the high thickness of volcanic deposits, a particularly attractive region in the context of the use of unconventional geothermal resources is the northwestern and western parts of the Gorzów block (Permian volcanics, Dębno region). Trachyandesites containing gaseous bubbles, i.e., 
rocks with potentially very good fracturing properties, were found in this region. The site was selected because of the geological analogy to the volcanic reservoir located in Gross Schoenebeck, near Berlin, where an EGS project is being carried out [47]. There are also favorable thermal conditions in this area: the geothermal gradient is $3.5-4.0^{\circ} \mathrm{C} / 100 \mathrm{~m}$ and the temperature approximately $160{ }^{\circ} \mathrm{C}$ at a depth of $4.3 \mathrm{~km}[22,25]$. The above locations may have significant potential for water-based EGS systems; however, from the point of view of research carried out for EGS installations using $\mathrm{CO}_{2}$ as a medium, the sedimentary cover is of key importance.

Sedimentary rocks occur in the vast majority of Poland, with the exception of the southwestern part (the Sudetes) [48]. The thickness of the sedimentary cover varies depending on the region. The largest volumes of sedimentary rocks are recorded in the central part of the Polish basin (9-12 km) as well as in the Carpathian (up to approximately $20 \mathrm{~km}$ ). The thinnest sediments, with a thickness of 0.3 to $1 \mathrm{~km}$, are found in the northeastern part of the EEC and in the Sudetes [41]. Two sedimentary structural complexes can be distinguished in Poland: (1) Cambrian to Silurian age-a lower unit and (2) Permian to Cenozoic age-an upper unit [49].

The analytical works conducted in sedimentary rocks have pointed out several potential areas for the construction of enhanced geothermal systems. In Poland, sedimentary rocks occur in the Polish Lowlands, the Carpathians and the Carpathian Foredeep. Due to the complex geological structure of the Carpathians (layer discontinuities, numerous tectonic zones) [50], this area is not attractive for EGSs. In the Carpathian Foredeep, one of the potential areas for energetic use of hot dry rock is the central part of the Upper Silesian Block (Figure 4, number 3). In this region, increased values of heat flow have been recorded. This is especially visible in the fold-belt areas of the Variscan areas and in the northern zone of the Lower Silesian internides, where heat flow values reached the highest measured level in Poland, exceeding $107 \mathrm{~mW} / \mathrm{m}^{2}$. The Upper Palaeozoic rocks of the Devonian and Carboniferous lie on the Precambrian and Lower Palaeozoic deposits in the form of a compact cover, although they are diversified in lithological and facial terms. The Lower Devonian rocks do not form a continuous cover, and they are characterized by a maximum thickness of $131 \mathrm{~m}$. The thickness of the Middle Devonian rocks measured in the boreholes ranges from $668 \mathrm{~m}$ to $1304 \mathrm{~m}$, and the thickness of the Upper Devonian carbonates reaches a maximum of $1046 \mathrm{~m}$. The Devonian rocks cover the Lower Carboniferous rocks. The lower part of the profile comprises carbonates (carbonate limestone facies) and clastic, flysch and flysch-like and molasses carbonaceous deposits, initially paralytic and above limestone, forming the Upper Silesian Coal Basin. The thickness of the carbonate deposits ranges from 200 to $1500 \mathrm{~m}$, while the complex of clastic Carboniferous deposits reaches a thickness of over $5000 \mathrm{~m}$ [51-53]. This complex of clastic Carboniferous deposits is a potential reservoir rock in the region of the Upper Silesian Block. At great depths, interesting for the purposes of this work, Carboniferous sandstones have a filtration value below $10^{-8} \mathrm{~m} / \mathrm{s}$ [54]. Unfortunately, at a cutting level of $5000 \mathrm{~m}$ b.s.l., the settlement complex now occupies only about half of the Upper Silesian Block (Figure 5), mainly in the western and central parts, as well as locally in the eastern one. Upper Carboniferous deposits are no longer present at this depth, and Lower Carboniferous are exposed in a narrow zone. It is also a zone of maximum rock temperature $\left(156-176{ }^{\circ} \mathrm{C}\right)$. In the area where Cambrian, Devonian and the Upper Devonian-Lower Carboniferous deposits outcrops, the forecast temperature reaches values from approximately $125^{\circ} \mathrm{C}$ to over $170{ }^{\circ} \mathrm{C}$ [55-57]. 


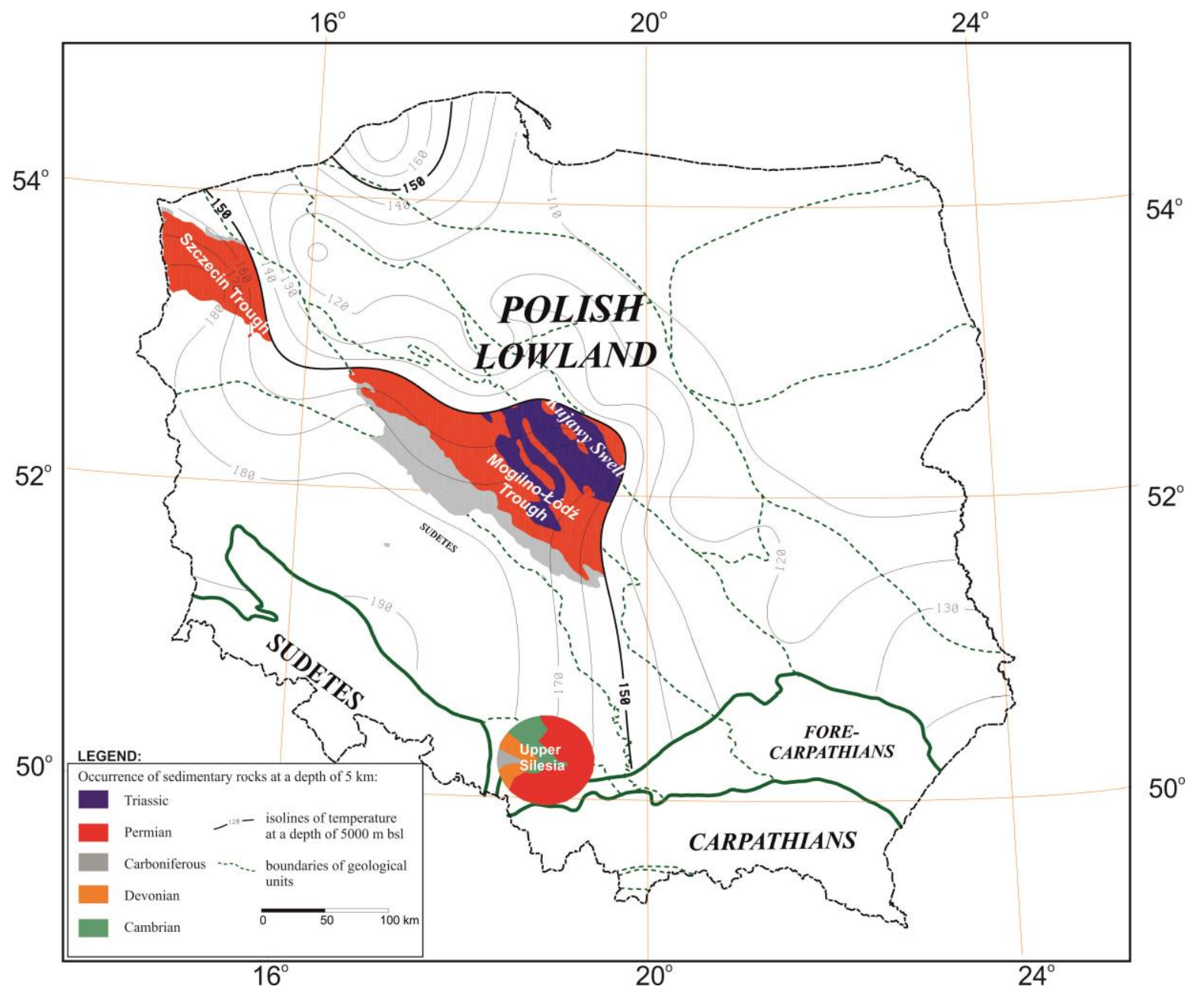

Figure 5. Map of the occurrence of sedimentary rocks at a depth of at least $5000 \mathrm{~m}$ and temperature of at least $150{ }^{\circ} \mathrm{C}$, divided into stratigraphic levels (based on data available in [58]).

In the Polish Lowlands, there are two interesting areas: the Szczecin Trough (Figure 4, number 1) and the region of the Mogilno-Łódź Trough (Figure 4, number 2). The Szczecin Trough is a strongly elongated element with a folded area. The folds cease to the southwest, changing direction from NW-SE to WNW-ESE [59]. The main tectonic factor that caused the current structure of the Zechstein-Mesozoic complex of the Szczecin basin was the diversified vertical movement of the blocks of the Sub-Zechstein basin, taking place mainly along the deep planes of tectonic discontinuities. These movements resulted in the differentiation of the pace and type of sedimentation, expressed in changes in the volume and facies, and the formation of erosive surfaces, as well as mechanical deformation of the overlying sedimentary complex. The second factor influencing the tectonic structure of the area is the horizontal and vertical displacements of the Zechstein salts, which occurred with slight interruptions practically throughout the entire sedimentation of the complex, starting from the Upper Triassic. These displacements were initiated by the movements of the blocks on the base of the salt series, and then interfered with these movements, which could be partially an autonomous process, controlled by density differences [60]. Along the Szczecin basin there is a zone of strong salt tectonics. The lithostratigraphic profile of the Szczecin Trough is made up of partially eroded and folded Carboniferous-Devonian deposits over which deposits of the Rotliegend and Zechstein deposits occur; the profile ends with the Mesozoic deposits covered with Cenozoic deposits. In this area, the prospects for EGSs should be associated with Permian or Carboniferous sediments lying at depths above $5000 \mathrm{~m}$ b.s.l. and characterized by temperatures above $150^{\circ} \mathrm{C}$ (Figure 5). The Szczecin area 
is a region of relatively weak geological recognition (a few deep boreholes), which resulted in problems in conducting reliable analyses.

The Mogilno-Łódź Trough (Figure 4, number 2) is part of a larger structure named the Szczecin-Mogilno-Łódź-Miechów Trough. The structure consists of three separate troughs-Szczecin, Mogilno-Łódź and Miechów-and stretches from the northwest to the southeast of Poland. From the southwest, this synclinorium borders upon the ForeSudetic Monocline, while its northwestern part continues beyond the western state border of Poland. The structure is filled up with the Upper Cretaceous sediments, being part of the Permian-Mesozoic sedimentary cover [61-64]. Vertical movements of blocks in the sub-Zechstein basement were the main factors that shaped the present-day structure of the Permian-Mesozoic complex. The Lower Permian is represented by strongly tectonically disturbed terrigenous deposits. These deposits are overlain by the Upper Permian rocks (Zechstein) developed in the salinar facies. A potential petrothermal reservoir in this area is the Lower Triassic deposits represented by the Buntsandstein rocks. The Lower Buntsandstein is developed as a monotonous complex of claystone-siltstone rocks with interbeds of oolitic limestones and sandstones. The Middle Buntsandstein is represented mostly by sandstones and siltstones, while the Upper Buntsandstein is developed as sandstone-claystone rocks of the sub-evaporitic complex (in the lower part of its profile) and thick carbonate-evaporitic deposits with intercalations of limestones, dolomites, anhydrites, gypsum, and halite (the upper part of the profile) $[65,66]$. In particular, dense sandstones of Lower Buntsandstein are considered as potential reservoir deposits for EGSs. The Lower Triassic formations are characterized by a large thickness, locally exceeding even $1500 \mathrm{~m}$, which is of great importance for enhanced geothermal systems. A different situation is related to the overlapping Middle Triassic (the Muschelkalk) deposits, where thicknesses do not exceed $300 \mathrm{~m}$. The Middle Triassic is developed as limestones with claystones and marls. The Upper Triassic is represented by the Keuper and the Rhaetian. The Lower Keuper is composed of interbedding clayey-silty-sandy sediments, and the Upper Keuper consists of claystones with numerous intercalations of anhydrite and halite. The Lower Rhaetian is developed as nodular claystones and clay conglomerates, claystones and silty claystones, and the Upper Rhaetian is represented by claystones and sandstones. The total thickness of the Upper Triassic deposits is greatest in the area of the Kujawy Swell, where it reaches values locally up to $2400 \mathrm{~m}$.

The younger Mesozoic and Cenozoic formations located above the Triassic formations are not subjects of interest for the EGS due to the depth of deposition and low values of temperature within the reservoirs. Moreover, sandstones of the Lower Jurassic and the Lower Cretaceous reservoirs are the most prospective hydrothermal reservoirs in the area of the Mogilno-Łódź Trough and also one of the most prospective in Poland.

Taking into account the criteria for selecting an optimum structure for enhanced geothermal systems in Poland, sedimentary rocks outcropping areas are the most suitable. It was found that the most promising conditions occur in area number 2 (Figure 4, Table 2)—the Mogilno-Łódź Trough with part of the Kujawy Swell (area no. 2). However, the Upper Silesian region (Figure 4, Table 2, area no. 3) is also characterized by very favorable conditions for such systems and seems to be a prospective location for the future.

Table 2. The most prospective areas in Poland for geothermal energy utilization in EGSs. Note: "area no." refers to numbered areas in Figure 4.

\begin{tabular}{ccc}
\hline Type of Reservoir Rocks & Area & $\begin{array}{c}\text { Reservoir Temperature } \\
{\left[{ }^{\circ} \text { C]/at Depth [m b.s.1. }\right]}\end{array}$ \\
\hline crystalline & Karkonosze & $165 / 4000$ \\
volcanic & Gorzów & $160 / 4300$ \\
sedimentary & Szczecin Trough (area no.1) & $150 / 5000$ \\
sedimentary & Mogilno-Łódź Trough (area no.2) & $165-195 / 5000-6500$ \\
sedimentary & Upper Silesian (area no.3) & $170 / 5000$ \\
\hline
\end{tabular}




\subsection{Carbon Capture and Storage (CCS)}

The best conditions for underground storage of $\mathrm{CO}_{2}$ occur in northern and central Poland (Polish Lowlands). In these regions, there are well-known geological sedimentary rocks of Mesozoic and Cenozoic age. Potential structures for $\mathrm{CO}_{2}$ sequestration were indicated in the Lower Cretaceous, Lower Jurassic and Lower Triassic formations in the Polish Lowlands [67] (Figures 4 and 5).

The interesting formations for EGS-CCS systems are the Lower Triassic formations, where in the central part of the basin, temperatures exceed $100{ }^{\circ} \mathrm{C}$. Furthermore, the Lower Cretaceous and Lower Jurassic reservoirs constitute basic hydrothermal reservoirs in the area of the Polish Lowlands characterized by considerable geothermal potential. Polish geothermal installations located in the Polish Lowlands use water from these reservoirs for energy purposes. Therefore, it is important to consider the Lower Cretaceous and Lower Jurassic reservoirs primarily as hydrothermal reservoirs. The situation is different in case of the Lower Triassic reservoir, which is characterized by a relatively low water content and thus has little prospect for the construction of conventional geothermal installations [26,27].

\subsection{An Optimum Structure for Enhanced Geothermal Systems with $\mathrm{CO}_{2}$ as a Working Fluid in Poland}

Combining the results of the above analysis for EGS and $\mathrm{CO}_{2}$ sequestration systems, the area with the greatest potential was the Mogilno-Łódź Trough (area no. 2). The Krośniewice-Kutno area was found to be the most promising zone for the EGS location (Figure 6). A petrothermal reservoir is made up of the Lower Triassic sandstones characterized by thicknesses exceeding $1000 \mathrm{~m}$. The analysis of the Lower Triassic reservoir parameters carried out in this region indicated the existence of rocks with appropriate parameters for the construction of the analyzed EGS- $\mathrm{CO}_{2}$ system in Poland. The top of the Lower Triassic formation on the area being analyzed is located on the study area at depths ranging from about 4000 to $6000 \mathrm{~m}$ under sea level, whereas in the location of a potential EGS installation, the Lower Triassic top occurs at depths ranging from 5000 to $5500 \mathrm{~m}$ below sea level. Reservoir rocks are characterized by an average porosity of about $2.5-3 \%$ and low permeability $(0.02-0.1 \mathrm{mD})$ and an average bulk density of about $2.7 \mathrm{~g} / \mathrm{cm}^{3}$ (Table 3 ). The sedimentary rocks are characterized by low porosity and permeability values, which-taking into account thermal conditions of a given region-qualifies them for use for potential petrothermal energy management. Temperatures at the top of the Lower Triassic reservoir range from 165 to $170{ }^{\circ} \mathrm{C}$, while in its deeper zones, higher temperatures up to $190^{\circ} \mathrm{C}$ can be expected. The reservoir overburden is built up from compact impermeable carbonate Muschelkalk formations (Figure 6, T2). Below there are Permian formations: Zechstein and Rotliegend (in Figure 6, P2 and P1, respectively).

Table 3. Average petrophysical parameters for selected petrothermal reservoir level (Lower Triassic) and the levels above and below [68].

\begin{tabular}{cccccc}
\hline Stratigraphy & $\begin{array}{c}\text { Bulk } \\
\text { Density } \\
{\left[\mathbf{k g} / \mathbf{m}^{3}\right]}\end{array}$ & Porosity $[-]$ & $\begin{array}{c}\text { Permeability } \\
{[\mathbf{m D}]}\end{array}$ & $\begin{array}{c}\text { Thermal } \\
\text { Conductivity } \\
{\left[\mathbf{W} / \mathbf{m}^{\circ} \mathbf{C}\right]}\end{array}$ & $\begin{array}{c}\text { Specific Heat } \\
{[\mathbf{J} / \mathbf{k g} \cdot \mathbf{C}]}\end{array}$ \\
\hline $\begin{array}{c}\text { Upper } \\
\text { Triassic }\end{array}$ & 2750 & 0.001 & 0.01 & 2.10 & 1000 \\
$\begin{array}{c}\text { Middle } \\
\text { Triassic }\end{array}$ & 2710 & 0.014 & 0.02 & 2.92 & 800 \\
$\begin{array}{c}\text { Lower } \\
\text { Triassic }\end{array}$ & 2710 & 0.025 & 0.1 & 2.40 & 950 \\
$\begin{array}{c}\text { Zechstein } \\
\text { Rotliegend }\end{array}$ & 2200 & 0.005 & 0.001 & 5.00 & 1000 \\
\hline
\end{tabular}



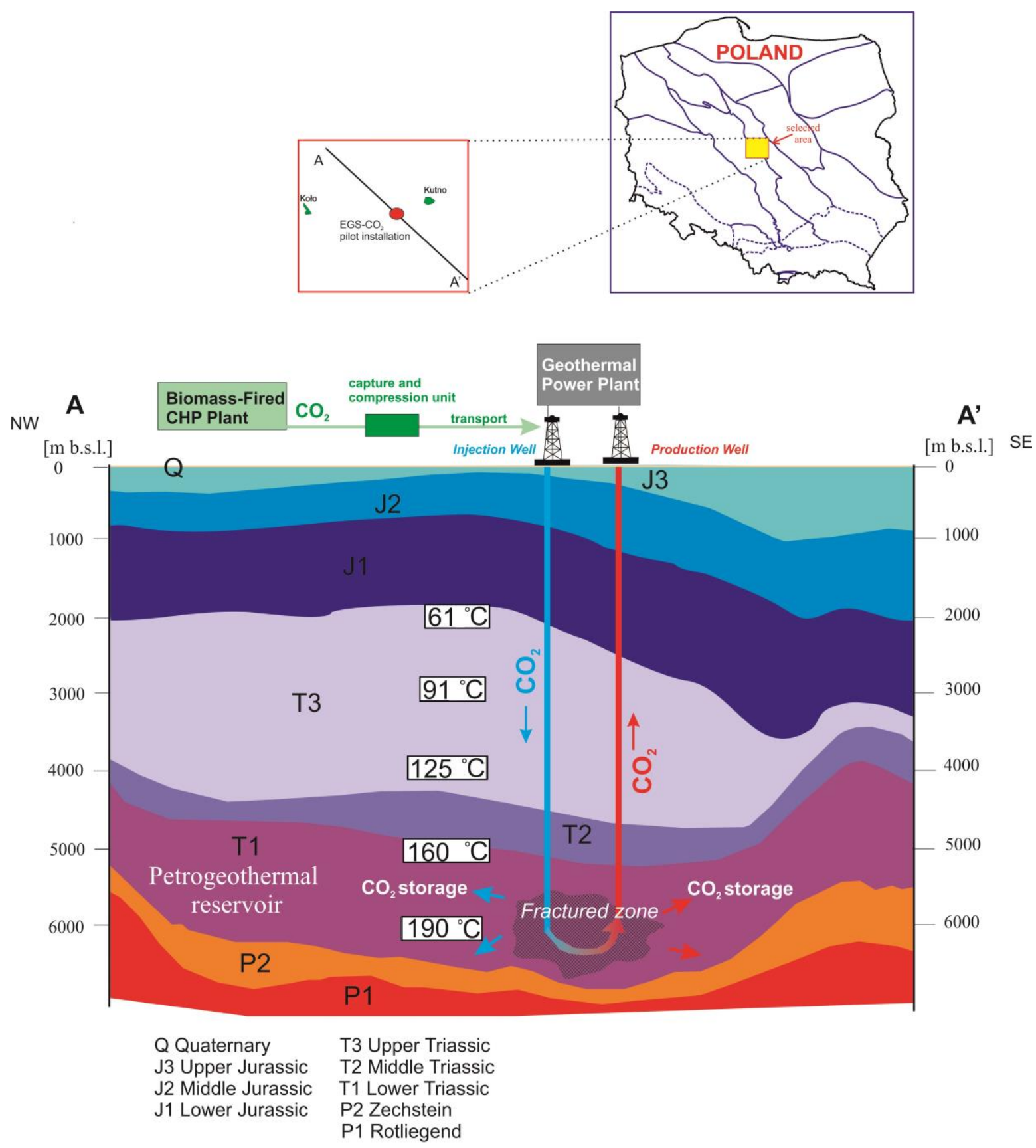

Figure 6. Geological cross-section through the selected area, together with the forecast distribution of the temperatures and schematic of the EGS- $\mathrm{CO}_{2}$ installation.

\section{Discussion}

Carbon dioxide is a key greenhouse gas, causing a number of negative environmental and health effects. Sustainable use of petrothermal resources in EGS- $\mathrm{CO}_{2}$ systems is aimed at reducing the amount of $\mathrm{CO}_{2}$ in the atmosphere through its capture and injection into a petrothermal reservoir. Such installations should be located near existing conventional heat and power plants using solid fuel such as coal or biomass (Figure 6). The use of biomass as a primary energy carrier results in negative $\mathrm{CO}_{2}$ emissions, due to absorption by plants. Because of the partial sequestration of $\mathrm{CO}_{2}$ circulating and used as working fluid in a geothermal EGSs, the mass balance of $\mathrm{CO}_{2}$ is not constant, as it is in case of biomass-fired power or heating plants. This conventional unit will be integrated with a $\mathrm{CO}_{2}$ capture and compression unit, a $\mathrm{CO}_{2}$ transport pipeline and a geothermal system 
comprising a geological reservoir and an $\mathrm{sCO}_{2}$ Brayton power cycle. Sustainable use of petrothermal resources may be related to the modernization of heat sources for small district heating, with up to $50 \mathrm{MWth}$ of installed power and energy production of $400 \mathrm{TJ} /$ year. This amount of energy refers to about $33,333 \mathrm{Mg}$ /year biomass used as the energy carrier (with the lower caloric value of $15 \mathrm{MJ} / \mathrm{kg}$ fired with an efficiency of 80\%). Assuming the emission factor of $\mathrm{CO}_{2}$ suitable for biomass fired on a mechanical grate is $1.33 \mathrm{~kg}$ $\mathrm{CO}_{2} / \mathrm{kg}$ biomass [69], the amount of $\mathrm{CO}_{2}$ utilized might be estimated as $44,333 \mathrm{Mg} /$ year. The economic as well as energy efficiency of such systems are strongly dependent on the adopted technical assumptions for the design of the entire installation. A very important element is the permeability of the reservoir zone after fracturing and the $\mathrm{CO}_{2}$ mass flow rate. These parameters will influence the efficiency of the EGS- $\mathrm{CO}_{2}$ installation. Therefore, the assessment of energy aspects will be strictly dependent on the adopted fracking parameters. The share of electricity and thermal energy in the final energy production strongly depends on heat demand. Electricity is easier to utilize, and its price is much higher, but the energy efficiency of converting heat into electricity in this range of temperature is usually lower than $15 \%$ net; thus, direct use of energy is more profitable from an economic point of view. Average yearly thermal energy losses in Poland reach $12 \%$; thermal energy has an efficiency of more than $80 \%[19,20]$.

Unconventional geothermal energy systems $\left(\right.$ EGS- $\left.\mathrm{CO}_{2}\right)$ can be used to produce electricity and heat in an environmentally friendly way. Apart from energy benefits, the added value of the operation of enhanced and integrated geothermal energy systems is the possibility of sequestration of carbon dioxide. An enhanced geothermal system can be located in zones of different types of rocks. More favorable thermal parameters occur with crystalline, igneous reservoirs than with sedimentary rocks. However, from the point of view of $\mathrm{CO}_{2}$ sequestration, sedimentary basins located in tectonically stable areas seem to be the best solution. Despite the less favorable temperature parameters, locally sedimentary basins also have the potential to become a commercially viable, sustainable and large-scale energy source.

Based on the present analysis of hydrogeological and thermal parameters in various areas of Poland, the structure located in central Poland in the region of Krośniewice-Kutno (Figure 6) seems to be the most promising for unconventional geothermal systems. Both the depth of the reservoir and the predicted thermal and petrophysical parameters of the Lower Triassic formations indicate that it is an optimal reservoir in Poland, combining the requirements of both systems (EGS and CCS). Taking into account the above aspects, the combination of geothermal development and $\mathrm{CO}_{2}$ sequestration will contribute to the reduction of carbon dioxide emissions as well as to the cost-effective generation of heat and/or electricity. Geothermal energy is a renewable, clean and ecological source of energy. Its use has many environmental benefits. The present challenge is to reduce emissions of $\mathrm{CO}_{2}$ in order to prevent significant climate change. The processes accompanying the injection of $\mathrm{CO}_{2}$ into deep aquifers can be used simultaneously for both sequestration and the associated clean energy production [70]. Unconventional geothermal installations are aimed at increasing the efficiency of energy use through the cogeneration of heat and electricity as well as the decarbonization of the energy sector.

Geological storage of $\mathrm{CO}_{2}$ is a very complex technical process involving the selection of a storage site, a mechanism for capturing carbon dioxide by a geological reservoir, assessing the storage capacity of gas in the reservoirs and monitoring it after storage [71,72]. Similar difficulties are related to the implementation of projects to develop petrothermal resources. The construction of EGSs requires significant investment costs, and the economic and energy effects are difficult to predict. Loss of $\mathrm{CO}_{2}$ can reach $1 \mathrm{t} / \mathrm{s}$ per $1000 \mathrm{MW}$ of electric capacity during the operation of EGS- $\mathrm{CO}_{2}$ systems. It can be assumed that a system with an installed capacity of $1000 \mathrm{MW}$ can store all the $\mathrm{CO}_{2}$ generated by a $3000 \mathrm{MW}$ coal-fired power plant $[10,73]$.

The first installations that could be built in Poland would have a much smaller capacity, but would be the first step towards further installations. The Polish energy sector 
is currently in a difficult situation; there is a need to search for alternatives to burning coal, which is the dominant energy source in Poland. One of the potential solutions is the use of geothermal energy. Hydrothermal resources are limited to zones of occurrence of reservoirs with favorable parameters. They are used to produce thermal energy. EGS systems could also produce electricity, and an additional benefit of systems that use $\mathrm{CO}_{2}$ as a medium would be the reduction of this gas in the environment.

At this stage, EGSs are still expensive systems [19], but, there is a visible trend in reducing costs for this type of installation. Before commercial installations are built in Poland, it is necessary to make a pilot installation that shows the legitimacy of implementing such solutions. The economic aspects of EGS- $\mathrm{CO}_{2}$ have been studied [20], and the levelized cost of energy (LCOE) was estimated at approximately $75 \mathrm{EUR} / \mathrm{MWh}$, which means that it would be economically justified only if government funding is applied.

The aim of this research and the considerations carried out by the authors seek to draw attention to the existing geological potential for EGSs in Poland. This potential is definitely greater than the hydrothermal potential, both in Poland and the rest of the world, but technological development does not allow for the efficient management of these resources in all cases. Therefore, it is reasonable to implement in Poland pilot installations in areas with favorable petrothermal conditions in order to create testing grounds and opportunities for the development of this type of resource. An innovative solution is the use of $\mathrm{CO}_{2}$ instead of water as a medium in EGSs. Though in the initial testing phases and with little global precedence, it seems that such a system could revolutionize the energy market due to the simultaneous production of energy and the injection of $\mathrm{CO}_{2}$ into geological formations. This process may also cause a number of problems, such as the escape of medium, carbon dioxide-rock interactions, and dissolution and precipitation of minerals, as indicated in the international literature [72,73]. It is important to note, however, that Poland has the geological potential for the use of petrothermal resources in enhanced geothermal systems, as is seen from the research conducted by the authors for the past 10 years. However, the determination of exploitation resources for such systems requires the creation of a EGS pilot installation.

\section{Conclusions}

Poland is a country that faces significant problems in terms of air pollution. Competitive solutions are sought to produce clean and green energy. It is necessary to increase the use of renewable energy resources, including geothermal resources, to obtain energy in an environmentally friendly way. One of these natural resources is petrothermal energy, associated with deeply buried hot dry rocks; these can be used in enhanced geothermal systems for heat and electricity production. In these systems, the medium can be water or carbon dioxide. Due to the additional environmental benefits of using $\mathrm{CO}_{2}$ as a medium, this article presents the possibilities of injecting carbon dioxide, which is the basic greenhouse gas contributing to climate change, in accordance with Polish geological conditions. The selection of the optimal structure for the location of such systems included the analysis of geological and thermal conditions suitable both for the construction of EGS systems and for the possibility of underground $\mathrm{CO}_{2}$ storage. The basic geological condition that determines the possibility of storing large amounts of $\mathrm{CO}_{2}$ underground is the presence of sedimentary rocks of large thickness, which are widely distributed and have good collecting properties, with an insulating rock overburden. Therefore, the area of Krośniewice-Kutno (central part of the Polish Lowlands) has been recognized as a prospective zone for the location of an EGS using $\mathrm{CO}_{2}$ as a medium. The prospective petrothermal reservoir is the clastic deposits of the Lower Triassic formation, with a porosity of $2.5 \%$ and a permeability approximately $0.1 \mathrm{mD}$. The top of the reservoir is $5000-5500 \mathrm{~m}$ b.s.l. The thickness of the reservoir rocks is over $1000 \mathrm{~m}$, while the temperature within the reservoir is in the range of $165-195{ }^{\circ} \mathrm{C}$. The indicated area is not the only one considered interesting for the construction of EGS- $\mathrm{CO}_{2}$ systems. In the future, attention may also be paid to other areas, including the Upper Silesia region or the Szczecin Trough. In order to care for the environment, it is necessary 
to develop natural resources in a sustainable way. An example of this is the production of electricity and heat with the use of petrothermal resources and the simultaneous injection of $\mathrm{CO}_{2}$.

Author Contributions: Conceptualization, A.S.; methodology, A.S.; software, A.S. and L.P.; validation, P.G., L.P. and A.S.; formal analysis, P.G.; investigation, A.S.; resources, A.S., L.P. and P.G.; data curation, A.S. and L.P.; writing—original draft preparation, A.S.; writing—review and editing, P.G. and L.P.; visualization, A.S.; supervision, P.G.; project administration, P.G.; funding acquisition, P.G. All authors have read and agreed to the published version of the manuscript.

Funding: This research was funded by the National Science Centre, Poland, within the grant 2017/24/C/ST8/00204.

Data Availability Statement: Data is contained within the article.

Acknowledgments: This work was developed thanks to support from the National Science Centre, Poland, within the grant 2017/24/C/ST8/00204.

Conflicts of Interest: The authors declare no conflict of interest.

\section{References}

1. Kamińska-Gawryluk, E. Green Economy Indicators in Poland 2019; Main Statistical Office, Statistical Office in Białystok: Warsaw/Białystok, Poland, 2019; p. 66.

2. Les Landes, A.A.; Guillon, T.; Peter-Borie, M. Locating Geothermal Resources: Insights from 3D Stress and Flow Models at the Upper Rhine Graben Scale. Geofluids 2019, 24, 8494539.

3. Moeck, I.S. Catalog of geothermal play types based on geologic controls. Renew. Sustain. Energy Rev. 2014, 37, 867-882. [CrossRef]

4. Brown, D.W.; Duchane, D.; Heiken, G.; Hriscu, V.T. Mining the Earth's Heat: Hot Dry Rock Geothermal Energy; Springer: Berlin/Heidelberg, Germany, 2012; p. 657.

5. Avanthi Isaka, B.L.; Ranjith, P.G.; Rathnaweera, T.D. The use of super-critical carbon dioxide as the working fluid in enhanced geothermal systems (EGSs): A review study. Sustain. Energy Technol. Assess. 2019, 36, 100547. [CrossRef]

6. Yao, C.; Shao, Y.; Yang, J. Numerical Investigation on the Influence of Areal Flow on EGS Thermal Exploitation Based on the 3-D T-H Single Fracture Model. Energies 2018, 11, 3026. [CrossRef]

7. Aminu, M.D.; Nabavi, S.A.; Rochelle, C.A.; Manovic, V. A review of developments in carbon dioxide storage. Appl. Energy 2017, 208, 1389-1419. [CrossRef]

8. Brown, D.W. A hot day rock geothermal energy concept utilizing super-critical $\mathrm{CO}_{2}$ instead of water. In Proceedings of the Twenty-Fifth Work-Shop on Geothermal Reservoir Engineering, Stanford, CA, USA, $24-26$ January 2000; Stanford University: Stanford, CA, USA; pp. 233-238.

9. Luo, F.; $\mathrm{Xu}, \mathrm{R} . ;$ Jiang, P. Numerical investigation of fluid flow and heat transfer in a doublet enhanced geothermal system with $\mathrm{CO}_{2}$ as the working fluid $\left(\mathrm{CO}_{2}\right.$ EGS). Energy 2014, 64, 307-322. [CrossRef]

10. Pruess, K. Enhanced geothermal systems (EGS) using $\mathrm{CO}_{2}$ as working fluid-a novel approach for generating renewable energy with simultaneous sequestration of carbon. Geothermics 2006, 35, 351-367. [CrossRef]

11. Pruess, K. On production behavior of enhanced geothermal systems with $\mathrm{CO}_{2}$ as working fluid. Energy Convers. Manag. 2008, 49, 1446-1454. [CrossRef]

12. Pritchett, J.W. On the relative effectiveness of $\mathrm{H}_{2} \mathrm{O}$ and $\mathrm{CO}_{2}$ as reservoir working fluids for EGS heat mining. Geotherm. Resour. Counc. Trans. 2009, 33, 235-239.

13. Kumari, W.G.P.; Ranjith, P.G. Sustainable development of enhanced geothermal systems based on geotechnical research-A review. Earth Sci. Rev. 2019, 199, 102955. [CrossRef]

14. Wakahama, H.; Mitoa, S.; Ohsumi, T.; Ueda, A.; Yajima, T.; Satoh, H.; Sugiyama, K.; Ozawa, A.; Ajima, S.; Todaka, N.; et al. A concept of $\mathrm{CO}_{2}$ georeactor sequestration at the Ogachi HDRsite, NE Japan. Energy Procedia 2009, 1, 3683-3689. [CrossRef]

15. Suto, Y.; Liu, L.; Yamasaki, N.; Hashida, T. Initial behavior of granite in response to injection of CO2-saturatedfluid. Appl. Geochem. 2007, 2, 202-218. [CrossRef]

16. Ueda, A.; Kato, K.; Ohsumi, T.; Yajima, T.; Ito, H.; Kaieda, H.; Metcalfe, R.; Takase, H. Experimental studies of CO2-rock interaction at elevated temperatures under hydrothermal conditions. Geochem. J. 2005, 39, 417-425. [CrossRef]

17. Olasolo, P.; Juárez, M.C.; Morales, M.P.; Olasolo, A.; Agius, M.R. Analysis of working fluids applicable in Enhanced Geothermal Systems: Nitrous oxide an alternative working fluid. Energy 2018, 157, 157,150-161. [CrossRef]

18. Randolph, J.B.; Saar, M.O. Combining geothermal energy capture with geologic carbon dioxide sequestration. Geophys. Res. Lett. 2011, 38. [CrossRef]

19. Gładysz, P.; Sowiżdżał, A.; Miecznik, M.; Pajak, L. Carbon dioxide-enhanced geothermal systems for heat and electricity production: Energy and economic analyses for central Poland. Energy Convers. Manag. 2020, 220, 1-17. [CrossRef]

20. Gładysz, P.; Sowiżdżał, A.; Miecznik, M.; Hacaga, M.; Pająk, L. Techno-economic assessment of a combined heat and power plant integrated with carbon dioxide removal technology: A case study for Central Poland. Energies 2020, 13, 2841. [CrossRef] 
21. Maćkowski, T.; Sowiżdżał, A.; Wachowicz-Pyzik, A. Seismic methods in geothermal water resource exploration: Case study from Łódź Trough, central part of Poland. Geofluids 2019, 2019, 3052806. [CrossRef]

22. Sowiżdżał, A. Geothermal energy resources in Poland-Overview of the current state of knowledge. Renew. Sustain. Energy Rev. 2018, 82, 4020-4027. [CrossRef]

23. Górecki, W.; Sowiżdżał, A.; Hajto, M.; Wachowicz-Pyzik, A. Atlases of geothermal waters and energy resources in Poland. Environ. Earth Sci. 2015, 74, 12. [CrossRef]

24. Sowiżdżał, A.; Górecki, W.; Hajto, M. Geological conditions of geothermal resource occurrences in Poland. Geol. Q. 2020, 64, 185-196. [CrossRef]

25. Wójcicki, A.; Sowiżdżał, A.; Bujakowski, W. (Eds.) Evaluation of Potential, Thermal Balance and Prospective Geological Structures for Needs of Unconventional Geothermal Systems (Hot Dry Rocks) in Poland; Ministry of the Environment: Warsaw, Poland, 2013 ; p. 246. (In Polish)

26. Sowiżdżał, A.; Papiernik, B.; Machowski, G.; and Hajto, M. Characterization of petrophysical parameters of the Lower Triassic deposits in a prospective location for enhanced geothermal system (central Poland). Geol. Q. 2013, 57, 729-743. [CrossRef]

27. Sowiżdżał, A. Possibilities of petrothermal energy resources utilization in central part of Poland. Appl. Ecol. Environ. Res. 2016, 14, 555-574. [CrossRef]

28. Bachu, S. Sequestration of $\mathrm{CO}_{2}$ in geological media: Criteria and approach for site selection in response to climate change. Energy Convers. Manag. 2000, 41, 953-970. [CrossRef]

29. Tarkowski, R. Geological Sequestration of $\mathrm{CO}_{2}$; Academy of Sciences, Studies, Dissertations, Monographs; Publishing House of the Institute of Mineral and Energy Economy of the Polish Academy of Sciences: Kraków, Poland, 2005; p. 132.

30. Holloway, S. Underground sequestration of carbon dioxide-A viable greenhouse gas migration option. In Proceedings of the 5thInt. Symp. On CO2 Fixation and the Efficient Utilization of Energy (C\&E 2002), Tokyo, Japan, 4-6 March 2002; Tokyo Institute of Technology: Tokyo, Japan, 2002.

31. Tarkowski, R.; Uliasz-Misiak, B. Geological structures (aquifers and hydrocarbon deposits) for underground $\mathrm{CO}_{2}$ storage in Poland. In Underground $\mathrm{CO}_{2}$ Storage in Poland in Deep Geological Structures (Oil, Gas and Aquifers); Tarkowski, R., Ed.; IGSMiE PAN Kraków: Kraków, Poland, 2005; pp. 69-111.

32. Wójcicki, A. National Program Recognition of formations and structures for safe geological storage of $\mathrm{CO}_{2}$ together with their monitoring plans. Biuletyn Państwowego Instytutu Geologicznego 2010, 439, 9-16.

33. Dubiński, J.; Wachowicz, J.; Koteras, A. Underground Carbon Dioxide Storage Possibilities of Using CCS Technology in Polish Conditions. Min. Geol. 2010, 5, 5-19.

34. Tarkowski, R.; Uliasz-Misiak, B. Prospects for the use of carbon dioxide in enhanced geothermal systems in Poland. J. Clean. Prod. 2019, 229, 1189-1197. [CrossRef]

35. Tester, J.W.; Anderson, B.J.; Batchelor, A.S.; Blackwell, D.D.; Dipippo, R.; Drake, E.M.; Garnish, J.; Livesay, B.; Moore, M.C.; Nichols, K.; et al. The Future of Geothermal Energy Impact of Enhanced Geothermal Systems (EGS) on the United States in the 21st Century. An Assessment by an MIT-Led Interdisciplinary Panel; Massachusetts Institute of Technology: Cambridge, MA, USA, 2006.

36. Lu, S.M. A global review of enhanced geothermal system (EGS). Renew. Sustain. Energy Rev. 2018, 81, 2902-2921. [CrossRef]

37. Tenzer, H. Development of Hot Dry Rock Technology. GHC Bull. 2001, 22, 1-9.

38. Sausse, J.; Dezayes, C.; Genter, A. From geological interpretation and 3D modelling to the characterization of the deep seated EGS reservoir of Soultz (France). In Proceedings of the European Geothermal Congress, Unterhaching, Germany, 30 May-1 June 2007.

39. Sowiżdżał, A.; Kaczmarczyk, M. Analysis of thermal parameters of Triassic, Permian and Carboniferous sedimentary rocks in central Poland. Geol. J. 2016, 51, 65-67.

40. Sowiżdżał, A.; Semyrka, R. Analyses of permeability and porosity of sedimentary rocks in terms of unconventional geothermal resource explorations in Poland. Geologos 2016, 22, 149-163. [CrossRef]

41. Majorowicz, J.; Polkowski, M.; Grad, M. Thermal properties of the crust and the lithosphere-asthenosphere boundary in the area of Poland from the heat flow variability and seismic data. Int. J. Earth Sci. 2019, 108, 649-672. [CrossRef]

42. Berthelsen, A. From Precambrian to Variscan Europe. In A Continent Revealed-The European Geotraverse; Blundell, D.J., Freeman, R., Mueller, S., Eds.; Cambridge University Press: Cambridge, MA, USA, 1992; pp. 153-164.

43. Dadlez, R.; Marek, S.; Pokorski, J. Geological Map of Poland without Cenozoic Formations, 1:1,000,000; Polish Geological Institute: Warsaw, Poland, 2000.

44. Szewczyk, J.; Gientka, D. Terrestrial heat flow density in Poland-A new approach. Geol. Q. 2009, 53, 125.

45. Grad, M.; Polkowski, M.; Ostaficzuk, S.R. High-resolution 3D seismic model of the crustal and uppermost mantle structure in Poland. Tectonophysics 2016, 666, 188-210. [CrossRef]

46. Santaa, G.D.; Galgaro, A.; Sassi, R.; Cultrera, M.; Scotton, P.; Mueller, J.; Bertermann, D.; Mendrinos, D.; Pasquali, R.; Perego, R.; et al. An updated ground thermal properties database for GSHP applications. Geothermics 2020, 85, 101758. [CrossRef]

47. Blöcher, G.; Reinsch, T.; Henninges, J.; Milsch, H.; Regenspurg, S.; Kummerow, J.; Francke, H.; Kranz, S.; Saadat, A.; Zimmermann, G.; et al. Hydraulic history and current state of the deep geothermal reservoir Groß Schönebeck. Geothermics 2016, 63, 27-43. [CrossRef]

48. Guterch, A.; Grad, M. Lithospheric structure of the TESZ in Poland based on modern seismic experiments. Geol. Q. 2006, 50, 23-32. 
49. Hajto, M.; Góecki, W. Geological analysis and assessment of geothermal energy resources in the Polish Lowlands. In Proceedings of the World Geothermal Congress 2010, Bali, Indonesia, 25-30 April 2010.

50. Górecki, W. (Ed.) Atlas of Geothermal Waters and Energy Resources in the Western Carpathians; Ministry of Environment, ZSE AGH: Krakow, Poland, 2011.

51. Buła, Z.; Żaba, J. The tectonic position of the Upper Silesian Coal Basin against the background of the Precambrian and Lower Palaeozoic subsoil. In Proceedings of the LXXVI Scientific Congress of the Polish Geological Society, Rudy near Rybnik: Geology and Environmental Protection Issues in the Upper Silesian Region, Warsaw, Poland, 14-16 September 2005.

52. Buła, Z.; Żaba, J.; Habryn, J. Tectonic regionalization of Poland-Southern Poland (Upper Silesian Block and Lesser Poland Block). Geol. Rev. 1998, 56, 10.

53. Żaba, J. Structural Evolution of the Lower Palaeozoic Deposits in the Border Zone of the Upper Silesian and Lesser Poland Blocks; Polish Geological Institute Works, CLXVI: Warsaw, Poland, 1999.

54. Różkowski, A. Hydrogeological environment of geothermal waters in the productive carbon formations of the Upper Silesian Coal Basin. In Geothermal Energy in Underground Mines; Małolepszy, Z., Ed.; Scientific Works of the Faculty of Earth Sciences, University of Silesia: Sosnowiec, Poland, 2001; p. 17.

55. Karwasiecka, M. Geothermal Atlas of the Upper Silesian Coal Basin; Polish Geological Institute: Warsaw, Poland, 1996.

56. Karwasiecka, M. Thermal field of the Upper Silesian Coal Basin. In Geothermal Energy in Underground Mines; Małolepszy, Z., Ed.; Scientific Works of the Faculty of Geosciences, University of Silesia: Sosnowiec, Poland, 2002; p. 17.

57. Karwasiecka, M. Rock mass temperature map at the level of -3000 m. In Atlas of Geothermal Energy Resources of the Upper Silesia Region; Solik-Heliasz, E., Ed.; GIG: Katowice, Poland, 2009.

58. Górecki, W. (Ed.) Atlas of Geothermal Resources of Mesozoic Formations in the Polish Lowlands; Ministry of Environment, ZSE AGH: Krakow, Poland, 2006.

59. Jaskowiak-Schoeneichowa, M. Geological Structure of the Szczecin Trough and the Gorzów Block; Polish Geological Institute, XCVI: Warsaw, Poland, 1979; p. 178.

60. Miecznik, M.; Sowiżdżał, A.; Tomaszewska, B.; Pajakk, L. Modelling geothermal conditions in part of the Szczecin Trough-The Chociwel area. Geologos 2015, 21, 187-196. [CrossRef]

61. Stupnicka, E. Regional Geology of Poland; Warsaw University Press: Warsaw, Poland, 1997.

62. Mizerski, W. Geology of Poland; Polish Scientific Publishers PWN: Warsaw, Poland, 2011; p. 4.

63. Karnkowski, P. Deep Geological Cross-Sections through the Polish Lowlands; Geological Publishers: Warsaw, Poland, 1980.

64. Narkiewicz, M.; Dadlez, R. Geological regionalization of Poland: General rules and scheme of division in undercenozoic and underpermian plain. Geol. Rev. 2008, 56, 5 .

65. Szyperko-Teller, A. The Lower Triassic. In Epicontinental Permian and Mesozoic in Poland; Marek, S., Pajchlowa, M., Eds.; Polish Geological Institute: Warsaw, Poland, 1997; Volume 153, pp. 83-132.

66. Sowiżdżał, A.; Hajto, M.; Hałaj, E. Thermal waters of central Poland: A case study from Mogilno-Łódź Trough, Poland. Environ. Earth Sci. 2020, 79, 1-11. [CrossRef]

67. Tarkowski, R.; Uliasz-Misiak, B.; Wójcicki, A. $\mathrm{CO}_{2}$ storage capacity of deep aquifers and hydrocarbon fields in Poland-EU GeoCapacity Project results. Energy Procedia 2009, 1, 2671-2677.

68. Bujakowski, W.; Barbacki, A.; Miecznik, M.; Pajak, L.; Skrzypczak, R.; Sowiżdżał, A. Modelling geothermal and operating parameters of EGS installations in the Lower Triassic sedimentary formations of the central Poland area. Renew. Energy 2015, 80, 44-453. [CrossRef]

69. The National Centre for Emissions Management (KOBiZE). The Indicators of Pollutants Emission Caused by Fuels Burning, Boilers with Thermal Power up to 5 MW; IOŚ-PIB: Warsaw, Poland, 2015.

70. Gosnold, W.D.; McDonald, M.R.; Klenner, R.; Merriam, D. Thermostratigraphy of the Williston Basin. GRC Trans. 2012, 36, 663-670.

71. Wójcicki, A. Geothermal Energy versus CCS and CCU. Biul. Państwowego Inst. Geol. 2012, 448, $239-246$.

72. $\mathrm{Wu}, \mathrm{Y}$; $\mathrm{Li}, \mathrm{P}$. The potential of coupled carbon storage and geothermal extraction in a $\mathrm{CO}_{2}$-enhanced geothermal system: A review. Geotherm. Energy 2020, 8, 19. [CrossRef]

73. Ajayi, T.; Gomes, J.S.; Bera, A. A review of $\mathrm{CO}_{2}$ storage in geological formations emphasizing modeling, monitoring and capacity estimation approaches. Pet. Sci. 2019, 16, 1028-1063. [CrossRef] 